\title{
The Educational Use of Social Media Sites by Pharmacy Students
}

\author{
Erin L. St. Onge ${ }^{1, *} \&$ Katie Hoehn ${ }^{1}$ \\ ${ }^{1}$ College of Pharmacy, University of Florida, Orlando, Florida, USA \\ *Corresponding author: College of Pharmacy, University of Florida, 6550 Sanger Road, Orlando, Florida 32827 , \\ USA. Tel: 1-407-313-7004. E-mail: stonge@cop.ufl.edu
}

Received: July 30, 2014

doi:10.5430/jct.v4n1p114
Accepted: April 2, $2015 \quad$ Online Published: May 7, 2015

URL: http://dx.doi.org/10.5430/jct.v4n1p114

\begin{abstract}
Social media sites are widely used among professional students and may offer an alternative means of communication for professors to utilize within their courses. Social media site usage has been characterized within healthcare education, however, data is lacking on its use within pharmacy programs. The purpose of this study was to evaluate social media use among pharmacy students at distance campus sites in order to determine student preferences and ways in which social media could be used within the pharmacy curriculum. A 12-item survey questionnaire was administered to first, second and third year students at three distance campus sites at the university of florida college of pharmacy. Pharmacy students surveyed most commonly reported using the social media site Facebook $^{\circledR}$ for school purposes, followed by Google $+^{\circledR}$. The majority of students from each class year reported using social media primarily to connect with fellow students or classmates. First and second year students most commonly use social media to keep up to date with events around campus, while third year students most commonly use social media sites to collaborate about a class or case. A common advantage to incorporating social media sites into pharmacy education was identified as keeping up to date with important dates and campus events, while the biggest disadvantage identified was that social media sites can be too distracting and time consuming. Social media sites may be used within pharmacy education as an alternative teaching modality.
\end{abstract}

Keywords: social media; pharmacy; education; student

\section{Background}

Social media sites are widely used among both young and older adults for purposes of networking, sharing and marketing. They are a way for individuals to connect with one another and to share similar interests and values. As of May 2013, it has been estimated that $72 \%$ of online U.S. adults use social networking sites (Brenner \& Smith, 2013). Due to the popularity of these sites, there has been a paradigm shift within social networking from face-to-face communication to a new technology based communication (Cain \& Fink, 2010). Students are also utilizing these social media sites for educational purposes. Current students are part of a newer technology based era known as Generation Y or the millennial generation (Piper, 2012). They commonly use social media sites, such as Facebook $^{\circledR}$, to connect with classmates, collaborate on group projects, and stay up to date with campus events. Group pages are being created for student organization information as well as for student courses.

Many studies have evaluated the role of social media in healthcare education, with an emphasis on student perception and usage (Giordano \& Giordano, 2011). As social media site usage continues to grow, it is beneficial to evaluate these tools as potential educational resources for young professionals in the healthcare field. The role of social media has been evaluated in medical (Lemley \& Burnham, 2009; Sandars, Homer, Pell, \& Croker, 2008), nursing (Lemley \& Burnham, 2009) and pharmacy students (Clauson, Singh-Franco, Sircar-Ramsewak, Joseph, Sandars, 2013; DiVall \& Kirwin, 2012). However, few studies have evaluated its use as an educational tool within pharmacy programs. Furthermore, studies conducted among pharmacy students did not elucidate ways in which social media can be integrated into the curriculum. A study conducted by Clauson, et al. in 2013 characterized social media use and student perceptions on its potential role within their education to a group of first year pharmacy students among a multi-campus college of pharmacy (Clauson et al., 2013). The students were administered a survey and their responses were recorded. Seventy-five percent of respondents felt that the educational integration of social media would impact their ability to learn in a positive way and $68 \%$ of respondents said it would make them feel 
connected. Another study conducted by DiVall and Kirwin used Facebook ${ }^{\circledR}$ to facilitate an online discussion within a course (DiVall \& Kirwin, 2012). The goal of this study was to encourage students to utilize the Facebook ${ }^{\circledR}$ discussion page for course-related content outside of the classroom. By the end of the course, $86 \%$ of students found the Facebook ${ }^{\circledR}$ page beneficial overall and $57 \%$ said they would miss the posts when the course ended. While the results from these studies suggest a role for social media in pharmacy education, it is not clear exactly how these sites should be incorporated into pharmacy coursework.

The purpose of our study was to evaluate social media use among pharmacy students at distance campus sites and to determine student preferences for ways in which social media can be used within the pharmacy curriculum. Students at the university of florida college of pharmacy were surveyed to assess their social media utilization as well as their thoughts on using social media to enhance their pharmacy education. Students were asked to name potential advantages and disadvantages of using social media sites within their pharmacy education. In addition, students were asked to list ways in which they felt professors in the college could incorporate these technologies into their coursework.

\section{Methods}

A survey questionnaire was developed and administered to all first, second and third year students at the university of florida college of pharmacy distance campus sites in Orlando, Jacksonville, and St. Petersburg. In order to maximize response rate, surveys were administered via paper after a required on campus class session. Students were asked to participate willingly; no incentives were provided for completion of the survey. Written informed consent was obtained from each student before administering the anonymous survey. The study was approved by the University of Florida Institutional Review Board.

The questionnaire collected demographic data such as gender, age, and geographical location. Social media use was characterized according to which forms of social media students use for school purposes (i.e. Facebook ${ }^{\circledR}$, Google $+^{\circledR}$, LinkedIn $^{\circledR}$, MySpace ${ }^{\circledR}$, Twitter ${ }^{\circledR}$, or other), how many hours per day students spend on social media sites, how often students check social media sites, and their primary reason for using social media sites. Social media use as it relates to pharmacy was characterized by why students use social media sites for pharmacy education (i.e. stay in touch with classmates, keep up to date with campus events, collaborate about a class, work on group projects, stay up to date on due dates, or other) and by which groups or pages students belong to that are school related. The last three questions on the survey were free response. Students were asked to list advantages and disadvantages to using social media in pharmacy education as well as list ways in which professors could incorporate social media into their courses to enhance learning. The survey administered can be found in Appendix A.

Data from the survey was analyzed using descriptive statistics. Respondents were categorized based on their gender, distance campus site and age. Participants were grouped into four categories based on age: 18-25, 26-35, 36-45, and 46-55. The aim of data analysis was to capture social media use and preferences in education between genders, campus sites, participant age and class year. Answers to the free response questions were analyzed and grouped into four categories determined by the authors as well as an outside third party individual to help reduce bias and increase reliability of the responses.

\section{Results}

Of the 512 total potential student respondents, 477 surveys were returned generating a $93.2 \%$ response rate. The majority of students were female (58.7\%) and most respondents were between the ages of 18 to 25 years (67.09\%). Class year $\left(1^{\text {st }}, 2^{\text {nd }}\right.$, and $3^{\text {rd }}$ year $)$ was nearly equal. Student demographic information can be found in Table 1. 
Table 1. Student Demographics ${ }^{a}$

\begin{tabular}{ll}
\hline Demographic & $\mathrm{N}(\%)$ \\
\hline Gender & $197(41.3 \%)$ \\
Male & $280(58.7 \%)$ \\
Female & $138(28.93 \%)$ \\
Campus & $179(37.53 \%)$ \\
Jacksonville & $160(33.54 \%)$ \\
Orlando & \\
St. Petersburg & $320(67.09 \%)$ \\
Age Group, Years & $132(27.67 \%)$ \\
18-25 & $21(4.4 \%)$ \\
26-35 & $4(0.84 \%)$ \\
36- 45 & \\
46-55 & $171(35.85 \%)$ \\
Year in Pharmacy School & $161(33.75 \%)$ \\
1PD & $145(30.4 \%)$ \\
2PD &
\end{tabular}

${ }^{\mathrm{a}} \mathrm{N}=477$.

An overwhelming number of students $(98.5 \%)$ reported using the social media site Facebook ${ }^{\circledR}$ for school purposes, followed by Google $+\circledR(34 \%)$ and "other" $(9.4 \%)$ (Figure 1). Furthermore, $60.2 \%$ of all students reported spending between one to five hours per day on social media sites and $43.2 \%$ of total students reported checking social media sites every couple of hours (Table 2). When asked what the primary reason was for using social media, males reported using sites to stay connected with friends and family, as well as connecting with fellow students or classmates. Females reported connecting with fellow students or classmates as the primary reason for using social media sites $(69.6 \%)$. This was also the primary reason for use when broken down based on class year (1PD, 63.2\%; 2PD, 67.7\%; 3PD, 68.3\%) (Table 3).

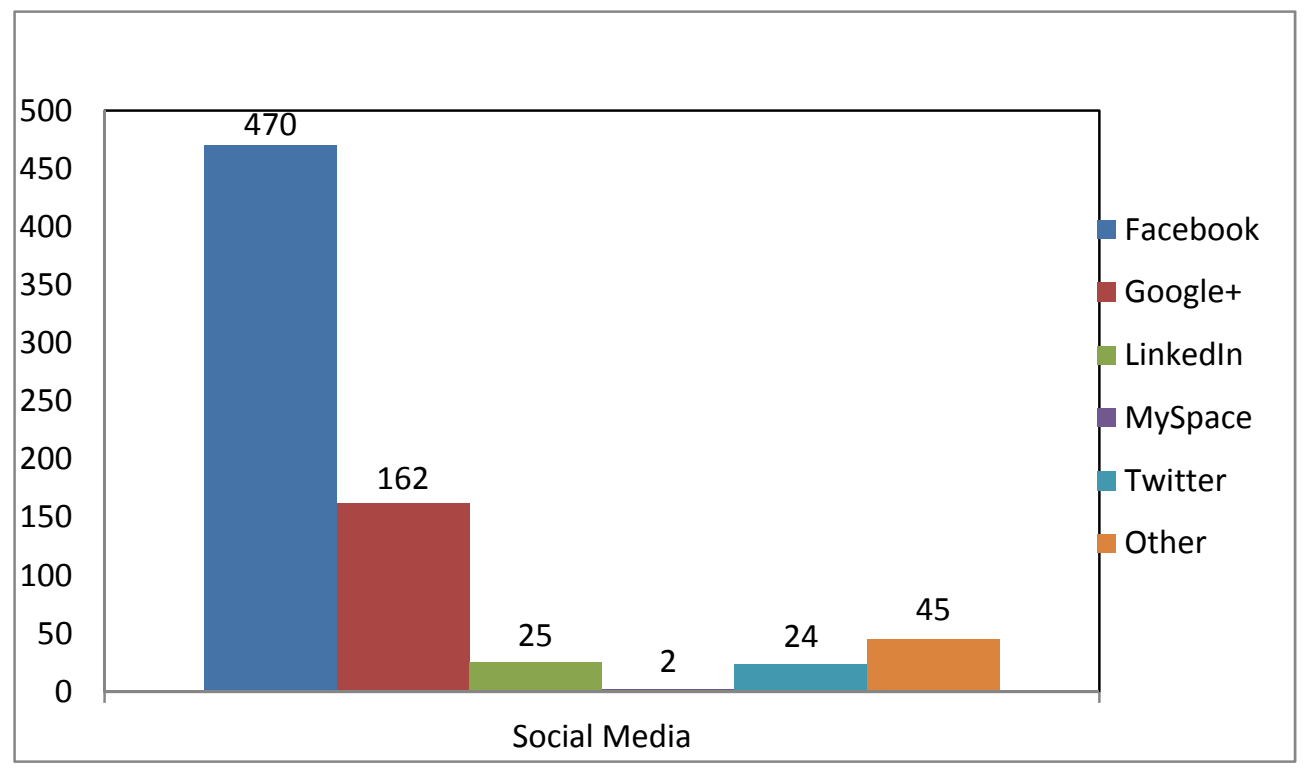

Figure 1. Forms of Social Media Use 
Table 2. Social Media Use

\begin{tabular}{cl}
\hline Hours spent per day on social media $^{\mathrm{a}}$ & $\mathrm{N}(\%)$ \\
\hline Less than 1 hour & $166(34.9 \%)$ \\
$1-5$ hours & $286(60.2 \%)$ \\
6-10 hours & $17(3.6 \%)$ \\
More than 10 hours & $6(1.3 \%)$ \\
\hline How often social media is checked ${ }^{\mathrm{b}}$ & \\
\hline Every couple of hours & $206(43.2 \%)$ \\
A few times a day & $197(41.3 \%)$ \\
Once a day & $44(9.2 \%)$ \\
Two to three times a week & $12(2.5 \%)$ \\
Once a week & $3(0.6 \%)$ \\
Other & $15(3.2 \%)$ \\
\hline
\end{tabular}

${ }^{\mathrm{a}} \mathrm{N}=475 .{ }^{\mathrm{b}} \mathrm{N}=477$.

Table 3. Primary Reason for Social Media Use

\begin{tabular}{clllll}
\hline & Friends and Family & Students or Classmates & Business & Other & Total \\
\hline $\begin{array}{c}\text { Gender } \\
\text { Male }\end{array}$ & $122(61.9 \%)$ & $121(61.4 \%)$ & & & \\
Female & $160(57.1 \%)$ & $195(69.6 \%)$ & $2(0.5 \%)$ & $7(3.6 \%)$ & 197 \\
Class Year & & & & $10(3.6 \%)$ & 280 \\
1PD & $98(57.3 \%)$ & $108(63.2 \%)$ & $0(0 \%)$ & $6(3.5 \%)$ & 171 \\
2PD & $98(60.9 \%)$ & $109(67.7 \%)$ & $0(0 \%)$ & $2(1.2 \%)$ & 161 \\
3PD & $86(59.3 \%)$ & $99(68.3 \%)$ & $3(2.1 \%)$ & $9(6.2 \%)$ & 145 \\
\hline
\end{tabular}

Results for social media use as it relates to pharmacy education can be found in Tables 4 and 5 . Most students reported using social media within their education to stay in touch with classmates, to keep up to date with events around campus, to collaborate about a class or a case, to work on group projects, and to stay up to date on due dates. Students reported belonging to the following groups or pages for school purposes: "Class of", club or organization, campus wide, school wide, and course project pages. First year and second year students report using social media sites primarily to keep up to date with events around campus (90.1\% and $83.2 \%$, respectively), while $86.9 \%$ of third year students use social media sites to collaborate about a class or a case. Amongst all categories analyzed, most students reported belonging to a "Class of" school related page.

Table 4. Social Media Use and Pharmacy Education

\begin{tabular}{clllllll}
\hline & Classmates & $\begin{array}{l}\text { Campus } \\
\text { Events }\end{array}$ & Classes/Cases & $\begin{array}{l}\text { Group } \\
\text { Projects }\end{array}$ & Due Dates & Other & Total \\
\hline $\begin{array}{c}\text { Gender } \\
\text { Male }\end{array}$ & $151(76.6 \%)$ & $158(80.2 \%)$ & $153(77.7 \%)$ & $140(71.1 \%)$ & $142(72.1 \%)$ & $11(5.6 \%)$ & 197 \\
$\quad \begin{array}{l}\text { Female } \\
\text { Class Year }\end{array}$ & & & & & & & \\
1PD & $132(76.8 \%)$ & $240(85.7 \%)$ & $240(85.7 \%)$ & $232(82.9 \%)$ & $240(85.7 \%)$ & $10(3.6 \%)$ & 280 \\
2PD & $124(77 \%)$ & $154(90.1 \%)$ & $142(83 \%)$ & $135(78.9 \%)$ & $135(78.9 \%)$ & $7(4.1 \%)$ & 171 \\
3PD & $110(75.9 \%)$ & $110(75.9 \%)$ & $126(86.9 \%)$ & $123(84.8 \%)$ & $122(84.1 \%)$ & $8(5.5 \%)$ & 145 \\
\hline
\end{tabular}


Table 5. School Related Groups and Pages

\begin{tabular}{ccllllll}
\hline & "Class of" & Club & $\begin{array}{l}\text { Campus } \\
\text { Wide }\end{array}$ & School Wide & $\begin{array}{l}\text { Course } \\
\text { Project }\end{array}$ & Other & Total \\
\hline $\begin{array}{c}\text { Gender } \\
\text { Male }\end{array}$ & $179(90.9 \%)$ & $116(58.9 \%)$ & $136(69 \%)$ & $114(57.9 \%)$ & $114(57.9 \%)$ & $7(3.6 \%)$ & 197 \\
$\begin{array}{c}\text { Female } \\
\text { Class Year }\end{array}$ & $262(93.6 \%)$ & $202(72.1 \%)$ & $207(73.9 \%)$ & $165(58.9 \%)$ & $165(58.9 \%)$ & $13(4.6 \%)$ & 280 \\
1PD & $155(90.6 \%)$ & $110(64.3 \%)$ & $125(73.1 \%)$ & $98(57.3 \%)$ & $107(62.6 \%)$ & $2(1.2 \%)$ & 171 \\
2PD & $151(93.8 \%)$ & $117(72.7 \%)$ & $117(72.7 \%)$ & $99(61.5 \%)$ & $81(50.3 \%)$ & $3(1.9 \%)$ & 161 \\
3PD & $135(93.1 \%)$ & $91(62.8 \%)$ & $101(69.7 \%)$ & $82(56.6 \%)$ & $91(62.8 \%)$ & $15(10.3 \%)$ & 145 \\
\hline
\end{tabular}

The free response question results are summarized in Tables 6,7 and 8 according to class year. The most common advantages listed for using social media within pharmacy education were to keep connected with classmates, to keep up to date with dates and campus events, an easy and fast form of communication, and a way to collaborate about course material. Each class year reported that the biggest advantage to using social media within their education was keeping up to date with dates and campus events. The most common disadvantages listed to social media use within pharmacy education included: sites are time consuming and distracting, lack of privacy and/or professionalism issues, potential for inaccurate information and an impersonal form of communication. Many first year students (42.7\%), second year students (36.6\%), and third year students (35.9\%) felt that social media sites would be too distracting and time consuming if utilized within their education. Students listed the following as ways in which professors within the college of pharmacy can incorporate social media sites into pharmacy education: a way to list announcements, assignments and due dates, a format to answer student questions, and a means of posting course resources. However, some students preferred that the college of pharmacy not incorporate social media sites into their education as they felt the online e-learning system already provided through the college was adequate. In fact, $24.8 \%$ of third year students disagreed with incorporating social media sites into their education. Other students felt that using social media sites within the pharmacy program would be an invasion of their privacy.

Table 6. Free Response: Advantages to Using Social Media in Pharmacy Education

\begin{tabular}{llllll}
\hline & $\begin{array}{l}\text { Keep Connected } \\
\text { with Classmates }\end{array}$ & $\begin{array}{l}\text { Keep Updated with } \\
\text { Dates/Events }\end{array}$ & $\begin{array}{l}\text { Easy and Fast } \\
\text { Communication }\end{array}$ & $\begin{array}{l}\text { Collaborate } \\
\text { Course Material }\end{array}$ & Total \\
\hline Class Year & & & & & \\
1PD & $28(16.4 \%)$ & $79(46.2 \%)$ & $59(34.5 \%)$ & $35(20.5 \%)$ & 171 \\
2PD & $28(17.4 \%)$ & $58(36 \%)$ & $47(29.2 \%)$ & $49(30.4 \%)$ & 161 \\
3PD & $27(18.6 \%)$ & $66(45.5 \%)$ & $47(32.4 \%)$ & $32(22.1 \%)$ & 145 \\
\hline
\end{tabular}

Table 7. Free Response: Disadvantages to Using Social Media in Pharmacy Education

\begin{tabular}{clllll}
\hline & $\begin{array}{l}\text { Time Consuming; } \\
\text { Distracting }\end{array}$ & $\begin{array}{l}\text { Privacy; } \\
\text { Professionalism Issues }\end{array}$ & $\begin{array}{l}\text { Inaccurate } \\
\text { Information }\end{array}$ & Impersonal & Total \\
\hline Class Year & & & & & \\
1PD & $73(42.7 \%)$ & $34(19.9 \%)$ & $6(3.5 \%)$ & $9(5.3 \%)$ & 171 \\
2PD & $59(36.6 \%)$ & $17(10.6 \%)$ & $6(3.7 \%)$ & $2(1.2 \%)$ & 161 \\
3PD & $52(35.9 \%)$ & $20(13.8 \%)$ & $2(1.4 \%)$ & $6(4.1 \%)$ & 145 \\
\hline
\end{tabular}

Table 8. Free Response: Ways Professors in the COP Can Use Social Media

\begin{tabular}{clllll}
\hline & $\begin{array}{l}\text { List Assignments; Due } \\
\text { Dates; Announcements }\end{array}$ & $\begin{array}{l}\text { Answer } \\
\text { Student } \\
\text { Questions }\end{array}$ & $\begin{array}{l}\text { Post Course } \\
\text { Resources }\end{array}$ & $\begin{array}{l}\text { Should Not be } \\
\text { Incorporated into } \\
\text { Education }\end{array}$ & Total \\
\hline $\begin{array}{c}\text { Class Year } \\
\text { 1PD }\end{array}$ & $55(32.2 \%)$ & $38(22.2 \%)$ & $9(5.3 \%)$ & $35(20.5 \%)$ & 171 \\
2PD & $32(19.9 \%)$ & $22(13.7 \%)$ & $6(3.7 \%)$ & $25(15.5 \%)$ & 161 \\
3PD & $29(20 \%)$ & $14(9.7 \%)$ & $10(6.9 \%)$ & $36(24.8 \%)$ & 145 \\
\hline
\end{tabular}




\section{Discussion}

This study evaluated the educational use of social media sites by pharmacy students across distance campus sites at the university of florida college of pharmacy. The results indicate that pharmacy students do indeed use social media sites in their pharmacy education. This is not unexpected as most students were between the ages of 18 to 25 years and belong to what is known as Generation Y (Piper, 2012). An overwhelming majority of students claimed to use Facebook $^{\mathbb{B}}$ for school related purposes and most students reported checking social media sites often throughout the day. This is true when comparing gender, campus as well as class year. Each class year reported using social media sites primarily to connect with fellow students or classmates and it was revealed that social media sites are already being utilized in several ways within pharmacy education.

Several limitations should be taken into account when the results from this study are analyzed. First, results from this study may not be generalizable to all pharmacy students since the study only involved first, second and third year students at distance campus sites at a single college of pharmacy. Students at distance campus education sites may be more reliant on technology for their education and thus may be more willing to incorporate social media sites into their education. Furthermore, not all pharmacy schools offer distance education sites within their pharmacy program. Another limitation of this study can be attributed to the design of the survey questionnaire. Students were able to pick more than one answer for some survey questions. Also, some questions were asked in a free response format which could falsely impact the results in a positive way since not all students responded to the free response questions. The degree of subjectivity should also be considered when it comes to interpreting the results and student answers to the free response questions as no two students responses were the same. Four main categories of responses were developed in order to try to reduce the ambiguity of the responses. Finally, one must take into account the legal and ethical issues that accompany social media use in education. Other pharmacy educators have pointed out that there are a number of basic rights that can be violated with the use of social media in education; including freedom of speech, search and seizure issues, right to privacy, and denial of due process (Cain \& Fink, 2010). However, social media sites still provide an excellent means of communication that can foster relationships between faculty, staff, and students. Open discussions amongst administration and faculty members regarding these issues should occur frequently and college honor codes should be examined and updated to reflect professionalism and social media use (Cain \& Fink, 2010).

Despite these limitations, this study revealed important information regarding how social media sites can be incorporated into the pharmacy curriculum. Several suggestions were made by students on ways in which professors can incorporate social media sites into their courses. Advantages and disadvantages in doing so were also listed. It seems as though utilizing social media sites such as Facebook ${ }^{\circledR}$ would be a positive platform in which professors could keep in touch with students, answer any questions they have, or post course resources. The results from this study may also be used to evaluate student preferences for social media use based on class year. Student needs related to their education seem to change as they progress further into the pharmacy curriculum. It appears as though first and second year pharmacy students would benefit the most if professors used social media sites as a fast and convenient way to communicate with them about course assignments, due dates and announcements. This approach may be beneficial for third year students as well; however, some third year students felt social media should not be incorporated into their pharmacy education.

\section{Conclusion}

Social media sites provide educators with an alternative teaching modality within healthcare education. Facebook ${ }^{\circledR}$ and Google $+{ }^{\circledR}$ were the two most commonly reported social media sites used among pharmacy students at distance campus sites. Professors in the college can utilize social media as a means to communicate with students regarding assignments and due dates. They can also use these sites as a platform to answer student questions and post course resources. Although social media sites were not originally intended to be used for educational applications, the ease and familiarity of their use by students makes them an ideal outlet for this purpose. The results from this study indicate that pharmacy students would encourage their professors in the college of pharmacy to use these social media sites as a way to enhance their education.

\section{References}

Brenner J., \& Smith A. (2013). 72\% of Online Adults are Social Networking Site Users. Pew Internet \& American Life Project, August 5, 2013. Retrieved November 11, 2013 from 
http://pewinternet.org/ /media//Files/Reports/2013/PIP_Social_networking_sites_update_PDF.pdf

Cain J., \& Fink JL. (2010). Legal and Ethical Issues Regarding Social Media and Pharmacy Eduation. American Journal of Pharmaceutical Education, 74(10), Article 184. http://dx.doi.org/10.5688/aj7410184

Clauson KA., Singh-Franco D., Sircar-Ramsewak F., Joseph S., \& Sandars J. (2013). Social Media Use and Educational Preferences Among First-Year Pharmacy Students. Teaching and Learning in Medicine, 25(2), 122-128. http://dx.doi.org/10.1080/10401334.2013.770742

DiVall MV., \& Kirwin JL. (2012). Using Facebook to Facilitate Course-Related Discussion Between Students and Faculty Members. American Journal of Pharmaceutical Education, 76(2), Article 32. http://dx.doi.org/10.5688/ajpe76232

Giordano C., \& Giordano C. (2011). Health Professions Students' use of Social Media. Journal of Allied Health, 40(2), 78-81.

Lemley T., \& Burnham JF. (2009). Web 2.0 Tools in Medical and Nursing School Curricula. Journal of the Medical Library Association, 97, 50-2. http://dx.doi.org/10.3163/1536-5050.97.1.010

Piper LE. (2012). Generation Y in Healthcare: Leading Millennials in an Era of Reform. Frontiers of Health Services Management, 29(1), 16-28.

Sandars J., Homer M., Pell G., \& Croker T. (2008). Web 2.0 and Social Software: The Medical Student Way of E-learning. Medical Teacher, 30, 308-12. http://dx.doi.org/10.1080/01421590701798729

\section{Appendix A}

\section{Project Title: The Educational Use of Social Media Sites by Pharmacy Students}

\section{Student Survey}

Demographics

1. Gender:
○ Male

$\circ$ Female

2. What campus do you attend?

○ Gainesville

- Jacksonville

○ Orlando

- St. Petersburg

3. Age group:

$\begin{array}{ll}\circ & 18-25 \\ \circ & 26-35 \\ \circ & 36-45 \\ \circ & 46-55\end{array}$

Social Media Use

4. What form(s) of social media do you use for school purposes? Check all that apply.
○ Facebook
○ Google +
○ LinkedIn
- MySpace
- Twitter
o Other:

5. How many hours per day do you spend on social media sites?

$\begin{array}{ll}\circ & \text { Less than } 1 \text { hour } \\ \circ & 1-5 \text { hours }\end{array}$ 
- 6-10 hours

- More than 10 hours

6. About how often do you check social media sites?

- Every couple of hours

- A few times a day

- Once a day

- Two to three times a week

○ Once a week

o Other:

7. What is your primary reason for using social media sites?

$\circ \quad$ To stay connected with friends and family.

- To connect with fellow students or classmates.

- To promote a business.

o Other:

Social Media Use and Pharmacy

8. Which of the following reason(s) do use social media sites for your pharmacy education? Check all that apply.

- To stay in touch with classmates

- To keep up to date with events around campus

- To collaborate about a class/case

○ To work on group projects

○ To stay up to date on due dates

o Other:

9. Which of the following groups/pages are you a part of that are school related? Check all that apply.

○ "Class of"

- Club or Organization

- Campus wide

- School wide

- Course Project

O Other:

Please answer the following questions:

10) Please list advantages to using social media sites in your pharmacy education:

11) Please list disadvantages to using social media sites in your pharmacy education:

12) Please list ways you feel professors in the COP can use social media sites to enhance your education: 